Arch. hist. jap. Vol. 15, n. 3 (October 1958).

P. 405-423.

Anat. Labor. of Prof. H. SETO, Tohoku University, Sendai.

\title{
On the Nerve Supply of Pharynx and Oesophagus of Snapping Turtle
}

\author{
スッポンの咽頭と食道の神絟分我飞就て。
}

Kota HOSHINA 保科孝太.

(Received August 4, 1958,)

At this laboratory, we are studying the histology and the innervation of various organs of some reptilia, in particular, snapping turtile and many interesting findings have been already reported. As a link of this chain of studies, the present author also has been granted the opportunity of conducting a similar research on the upper part of the digestive cannal, namely, the pharynx and the oesophagus, of snapping turtle. As far as I could make sure, these parts of snapping turtle have never been treated for such studies and even histological studies of the parts of man and other animals have been only very sparse, the innervation of the human pha. rynx having been studied by none other but SATO of this laboratory, and only an extremely few research reports have ever appeared on the human and mammalian oesophagi and nearly none when we seek for sutdies dependable for the accuracy of observation.

The materials of my study were fixed in $10 \%$ neutral formol for a long time and cut into $40 \mu$ serial cross-sections which were stained with SETO's impregnation in routine used at this laboratory. The very copious series of very beautifully stained preparations thus obtained were thoroughly examined and many an interesting finding was obtained, as reported hereunder.

\section{Individual Findings.}

Prior to a descriptin of the innervation of the pharynx and the oesophagus of Japanese snapping turtle, I wish to speak on their microscopical anatomy,

The pharyngeal mucous membrane of this reptile (Figs. 1 and 2) consițs of a nonhornified stratified flat epithelium usually thick but rich in variety of thickness and a lamina propria mucosae of fibrous connective tissue relatively rich in lymphocytes, and since the lamina muscularis mucosae is absent as in man and other animals, the boundary between the propria and the submucosa of more or less lose connective tissue is often blurred. In the submucosa, however, rather thick blood vessels, especially, blood capillaries are distinctly visible and subepithelially, groups of lymphocytes and solitary lymphonodules are frankly notable, but I could scarcely find any germ centers in them. More or less branched pigment fibrocytes are found here and there in the submucosa and the propria. These are found more of ten running along the blood vessels, but not rarely along the nerve bundles also. No mucous glands as found in this part of man and other animals can ever be found 


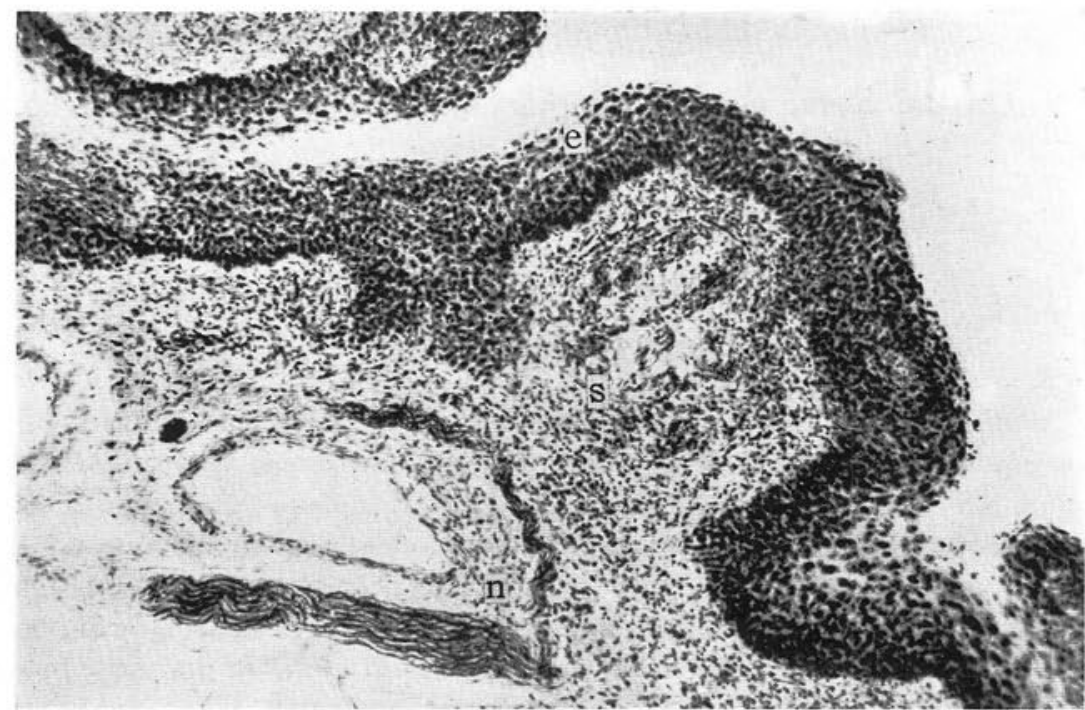

Fig. 1. A Pharyngeal papilla similar to the papilla fungiformis linguae found in the pharynx of a snapping turtle. Cross section. $e$ unhornified stratified flat epithelium, $s$ papillar stock, $n$ thick nerve bundle in submucosa. SETO's impregnation. Photo $\times 100$.

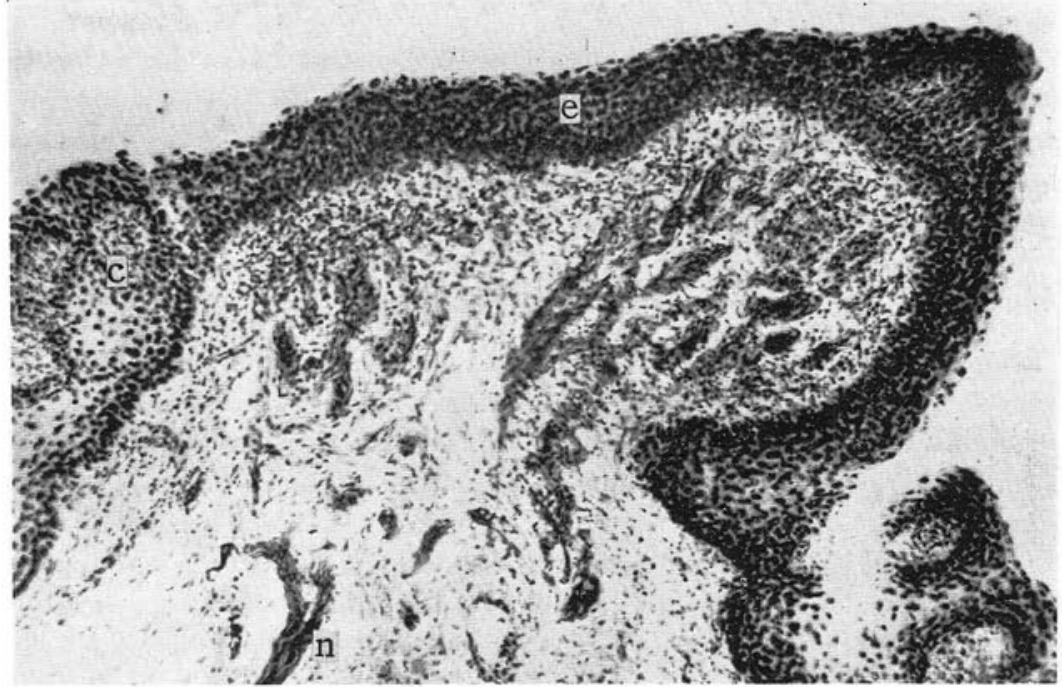

Fig. 2. A Pharyngeal papilla similar to the papilla circumvallata linguae found in the pharynx of a snapping turtle. Cross section. $e$ epithelium, $c$ secondary papillae, $n$ nerve bundles in the papillar stock. Same staining. Photo $\times 100$.

in the propria or the submucosa of the pharynx of this animal. On the outermost side, the submucosa is lined by a series of pharyngeal constrictor muscles consisting of striated muscle fibres.

Now, in the pharynx of my Japanese snapping turtle, I found very notable 
peculiar formations not to be sought for in the pharynges of man and other animals - a number of projections from the mucous membrane, so large as to be readily observed macroscopically in the impregnated cross-sections. These at first glance

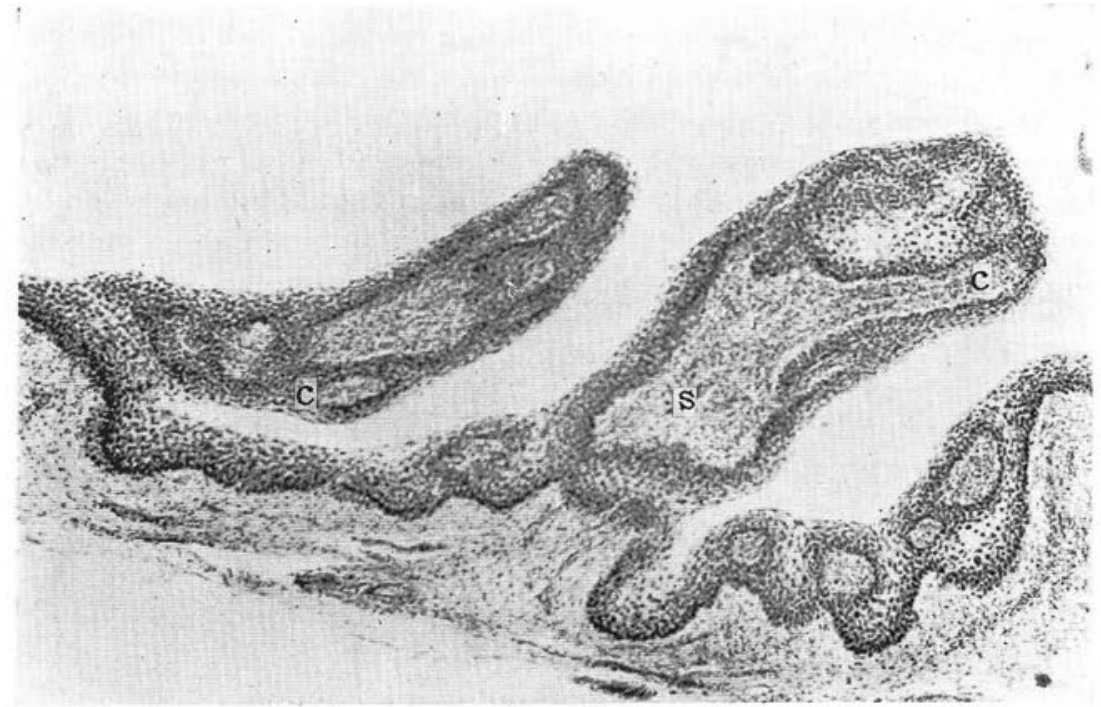

Fig. 3. 2 long pharyngeal papillae similar to the papillae foliatae linguae found in the pharynx of a snapping turtle. Cross section. $s$ papillary stock, $c$ secondary papillae. Same staining. Photo $\times 60$.

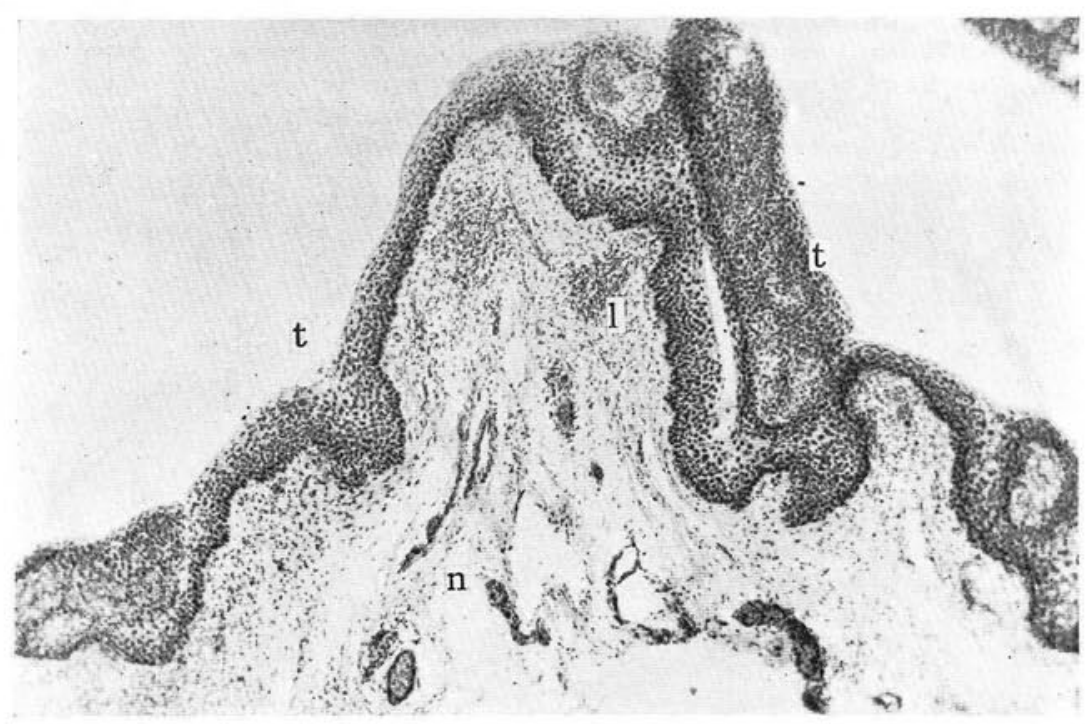

Fig. 4. A large triangular pharyngeal papilla $(t)$ and a long one $\left(t^{\prime}\right)$ in the pharynx of a snapping turtle. Cross section. $l$ lymphocytes gathering and $n$ nerve bundles containing a few ganglion cells in the papillar stock. Same staining. Photo $\times 60$. 
may appear as cross-cut mucous folds, but microscopically examined, they are found to be formations similar to the lingual papillae consisting of projecting and epithelium-covered propria, that is, papillary stocks, which of ten send out secondary papillae into the epithelium. I wish to call these the "pharyngeal papillae".

These pharyngeal papillae are variable in size and shape, some resembling the papillae foliatae of the tongue (Figs. 3 and 4), some the papillae fungiformes (Figs. 6 and 7 ) and some again the papillae circumvallatae (Fig. 1). The papillae in the pharynx, however, show no hrnification of their epithelium and contain no tastebuds. Some contain very numerous secondary papillae (Fig. 5) but some other only a relatively small number of them (Fig. 4). I may say, it is of high interest that such papillae are found in a large numbar in the pharynx of this lowly reptile.

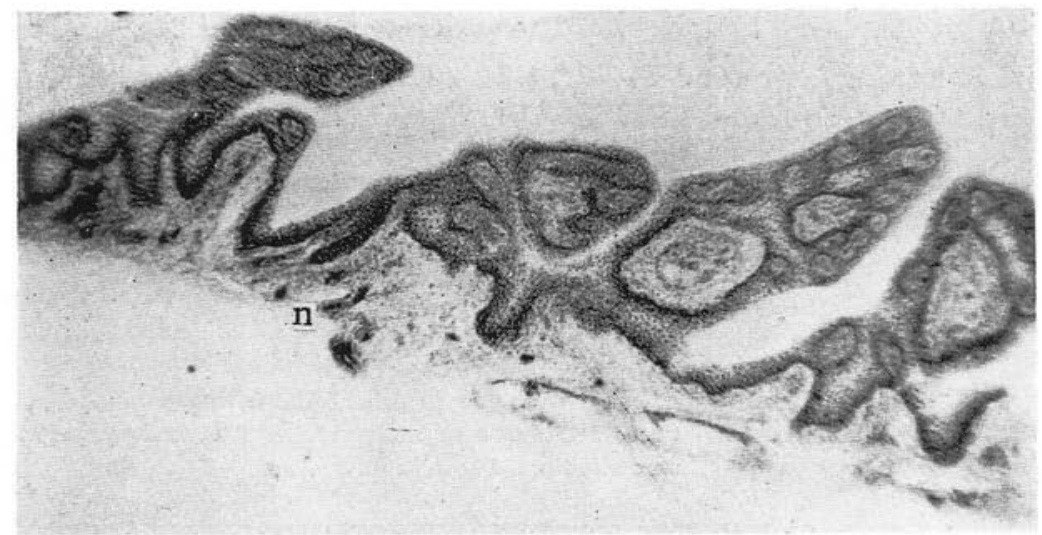

Fig. 5. Various formed pharyngeal papillae rich in secondary papillae found in the pharynx of a snapping turtle. Cross section. $n$ nerve bundles in submucosa and propria. Same staining. Photo 40.

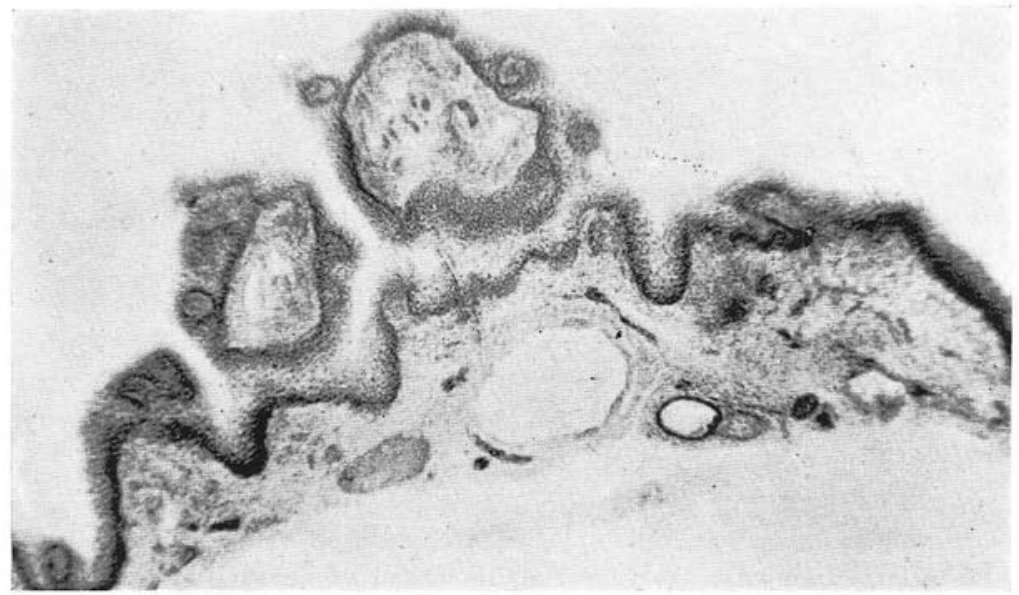

Fig. 6. 2 large pharyngeal papillae similar to the papillae fungiformes linguae found in pharynx of a snapping turtle. Cross section. Same staining. Photo $\times 40$. 


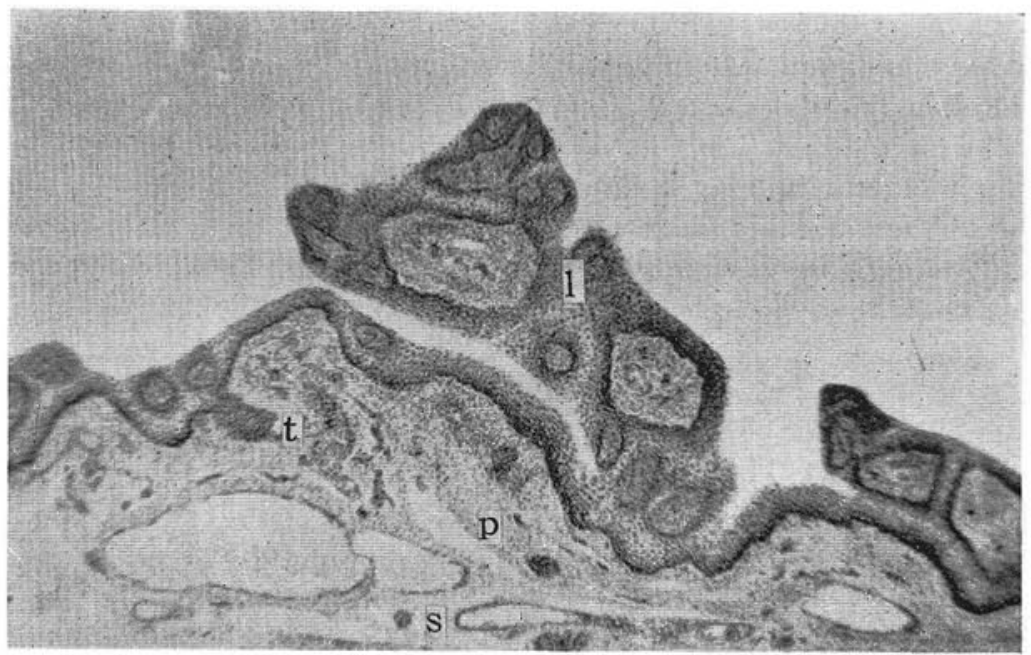

Fig. 7. A large long pharyngeal papilla $(l)$ rich in secondary papillae and a low triangular one $(t)$ found in the pharynx of a snapping turtle. Cross section. $s$ submucosa, $p$ propria. Same staining. Photo $\times 60$.

These pharyngeal papillae gradually lose in height distalwards and go out of existence near the distal end of the pharynx.

In the oesophagus, as shown in Figs. 8 and 9, the mucous membrane forms many longitudinal mucous folds, as is usual in animal oesophagi. The epithelium

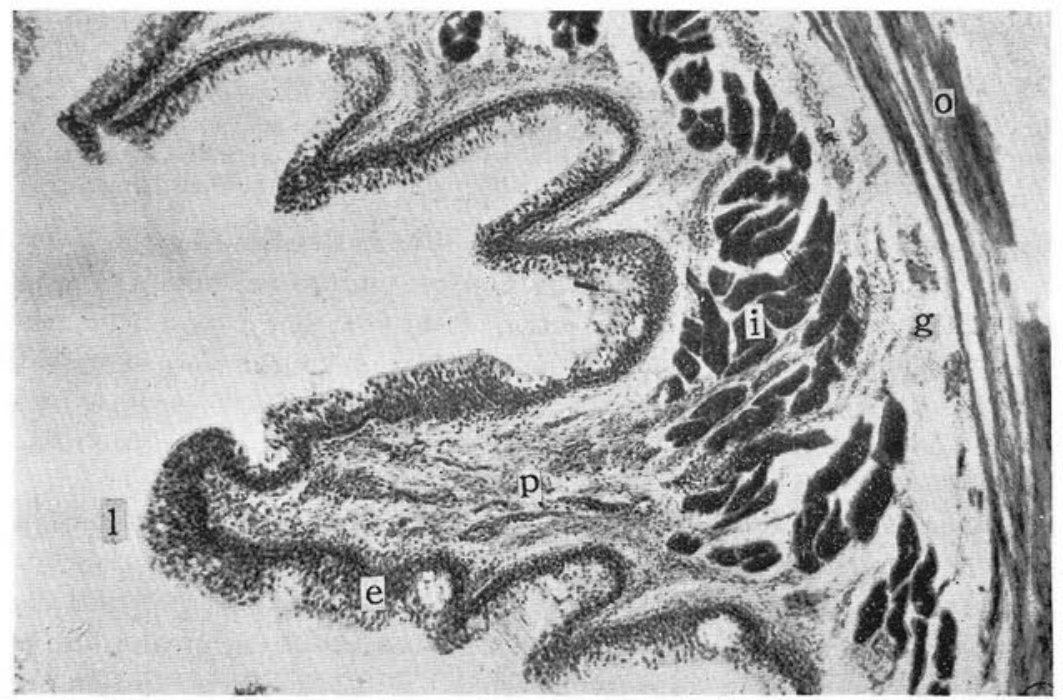

Fig. 8. Across section of oesophagus of a snapping turtle. $l$ large longitudinal mucous fold, $e$ stratified cylindrical epithelium here and there containing intraepithelial mucous glands, $p$ propria, $i$ inner longitudinal muscle layer of striated nature, $o$ outer circular muscle layer of smooth nature, $g$ small ganglia in the AUERBACH's plexus. Same staining. Photo $\times 60$. 
here is a rather thick stratified cylindrical epithelium and, to my interest, was found to contain many intraepithelial glands of mucous nature. The propria is of fibrous connective tissue and is rich in capillaries and small blood vessels. The muscularis mucosae, as found outside the propria in mammals, is absent in the oesophagus of Japanese snapping turtle. The submucosa is composed of a fibrous connective tissue arranged somewhat loosely and contains rather thick blood vessels. This submucosa is in frank existence in the medial parts of the ventral and the dorsal sides of the oesophagus (Fig. 9), but not in its lateral sides, where the corres-

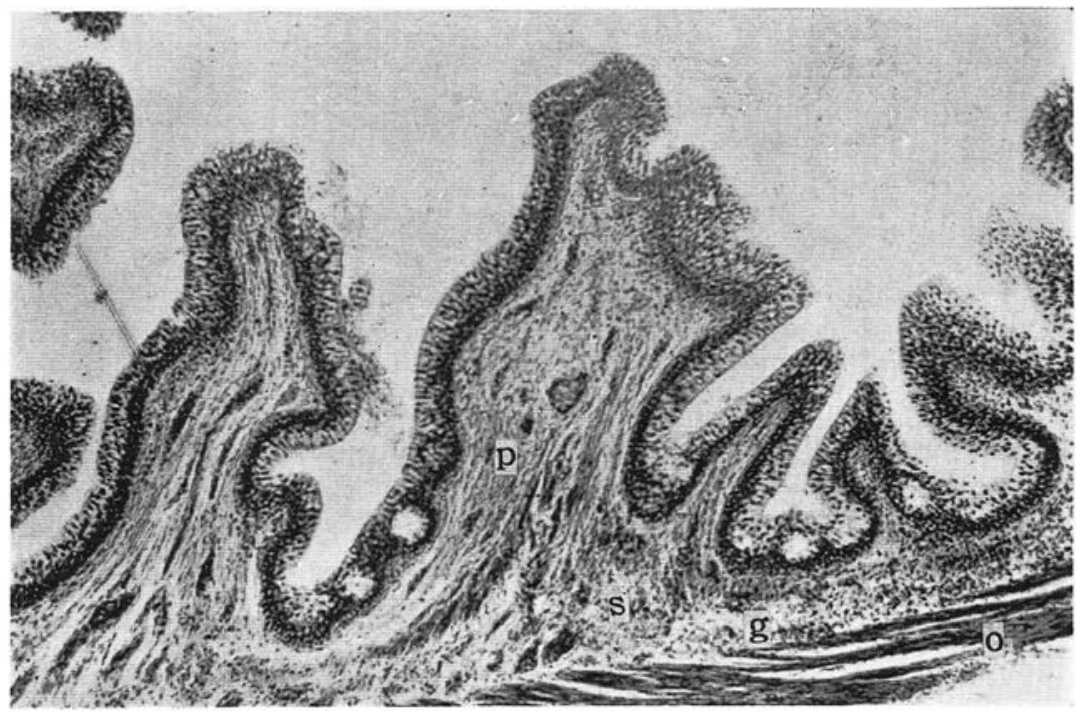

Fig. 9. Ditto. Large and small longitudinal mucous folds are seen, $p$ propria, $s$ submucosa in place of the inner longitudinal muscle layer, $o$ outer circular smooth muscle

layer, $g$ small ganglion in the MEISSNER's plexus. Same staining. Photo $\times 60$.

fonding spaces are taken up by the inner longitudinal striated muscle layer described in the following (Fig. 5). The muscularis comprises an inner and an outer layers. The former is formed by transition of the pharyngeal constrictor muscles of striated muscle tissue and running longitudinally, takes the place of the submucosa in the lateral sides of the oesophagus, as stated above. This inner layer becomes less well developed gradually distalwards. The outer layer of the muscularis forms a complete circular layer throughout and is made of smooth muscle tissue.

The nerves supplied to the pharynx, in snapping turtle as well as perhaps in all non-human animals, originate in the plexus pharyngeus formed by the pharyngeal rami of the vagal nerves, the glossopharyngeal nerves and the cervical sympathetic cords, the sensory, the motor and the parasympathetic nerve fibres being derived from the vagal and the glossopharyngeal nerves and the sympathetic nerve fibres from the cervical sympathetic cords.

The plexus pharyngeus is formed outside the constrictor muscle layer of the pharynx, and the nerve bundles sent out therefrom run through the intermuscular connective tissue into the submucosa and the propria. Meanwhile, the motor nerve 
fibres alone end upon spreading out in the constrictor muscles. Now, as stated above, the pharyngeal mucous membrane of snapping turtle is provided with powerful papillae resembling the lingual papillae. Therefore, we may easily conjecture that the mucous membrane would be rich in sensory fibres, for many works at this laboratory concerning the lingual papillae have taught us to expect finding strong innervation of such papillae. In fact, I found nerve plexus of considerable complexity and containing numerous sensory fibres in the submucosa and the propria here, in particular, in the papillary stocks of pharyngeal papillae (Figs. 1, 2, 5, 6 and 14).

It is well known that a small number of small ganglion cells of sympathetic nature are found in the nerve plexus found beneath the lingual papillae, especially, the vallated and the fungiform papillae of man and some animals (NAKAYAMA and others). In the pharyngeal papillae of snapping turtle too, small ganglion cells were found, singly or by twos and threes, not only in the submucosal and the proprial plexus beneath the papillae (Fig. 4), but also in the plexuses in the papillary storks as well as in the secondary papillae (Fig. 14). These ganglion cells, of ten showing weak multipolarity (Fig. 11), must be of sympathetic nature, but the nerve processes are very fine and very hard to stain, so that very many of them appear as apolar cells (Fig. 11).

The nerve plexuses formed in the mucous membrane of snapping turtle are composed of very fine nonmedullated vegetative fibres and thick medullated sensory fibres (Figs. 10 and 11). The existence of periarterial vegetative plexus formed along the blood vessels, especially, the arteries beside the above and the frequent anastomosis effected between the perivascular plexus and the vegetative fibres from the proper pharyngeal nerves in the pharyngeal mucous membrane are findings

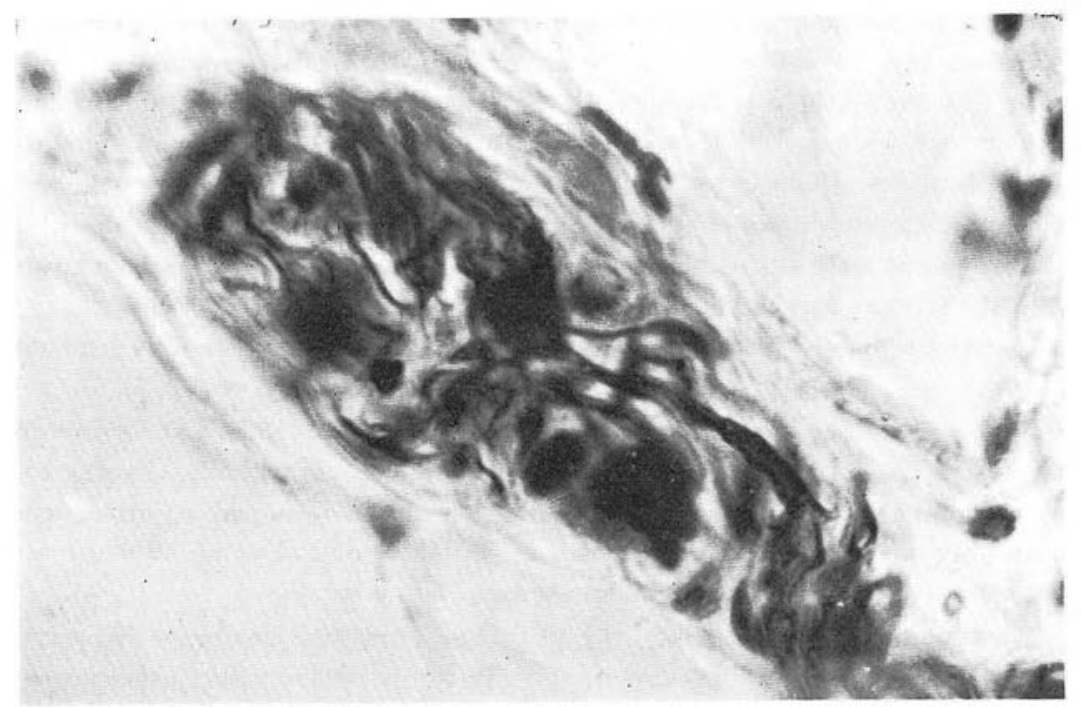

Fig. 10. High magnification of Fig. 4 n. The multipolarity of the ganglion cells is clarified. Photo $\times 800$. 


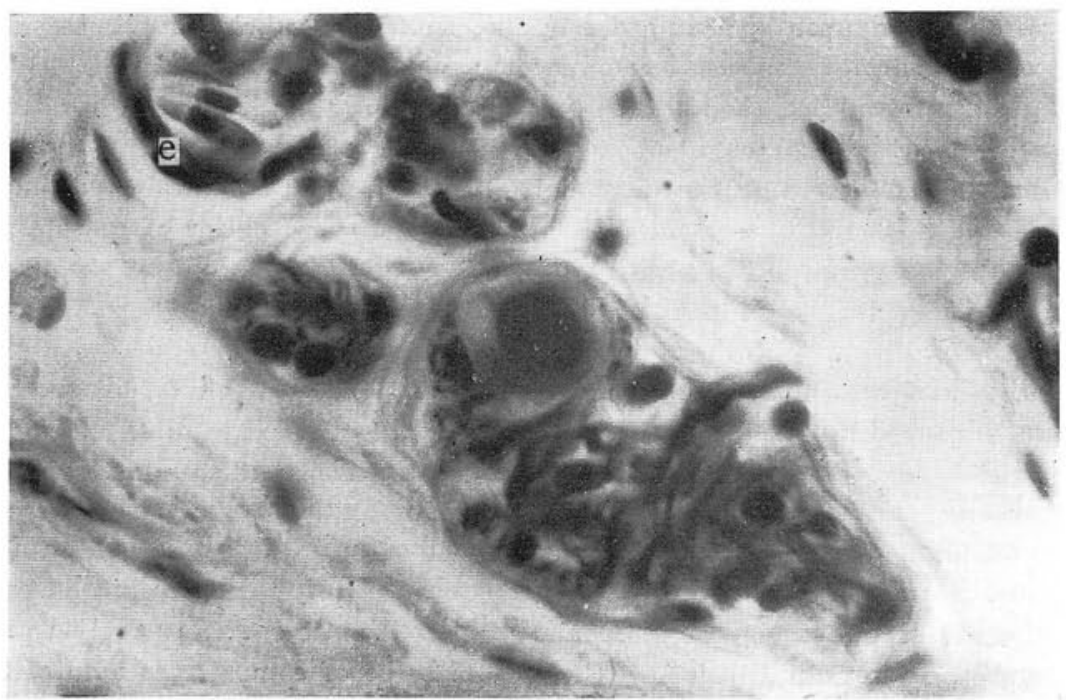

Fig. 11. A ganglion cell of apolar type found in a small nerve bundle running in the propria of the pharynx of a snapping turtle. $e 2$ erythrocytes with a cell nucleus in a small vein. Same staining. Photo $\times 800$.

common to the pharynges of snapping turtle and other animals, including man. The vegetative fibres in this part too end in STÖHR's terminal reticula upon wide diffusion in the connective tissue of the submucosa and the propria containing papillary stocks - another feature similar to the terminal mode of vegetative fibres in man and other animals.

In the human pharynx, no free projecting papillae comparable to the lingual papillae are ever formed and even the common small papillae growing out of the propria into the epithelium are only ill developed, so that the sensory nerve supply to the mucous membrane in this part is also very poor. So only a small number of simple subepithelial sensory terminations and a very few unbranched and simple branched intraepithelial fibres have been observed here, except in the dorsal side of the laryngeal wall of the lower part of the pharynx where the papillae and accordingly the sensory terminations were found better developed (SATO).

In the snapping turtle, however, the pharynx is richly provided as stated above with various well-developed pharyngeal papillae, so that it is needless to say the supply of sensory fibres here must be very powerful. But in the turtle pharynx, no such highclass complex terminations as glomerular terminations and very complex branched terminations, as found in the human lingual papillae, can be found, only such simple types comprising simple branched or unbranched terminations usually found in lower animals being represented.

These sensory terminations in the pharyngeal mucous membrane of snapping turtle are formed in the propria, most of ten in the papillary stock just beneath the epithelium, They sometimes originate in very thick sensory fibres (Fig. 16) but mostly in medium-sized medullated fibres, which, after losing their myelin sheaths, 
end unbranched or upon simple branching. Their terminal fibres run one of the two following types of courses: the one type is represented by comparatively straight courses and the other by looped coorses, the fibres of the latter type not rarely running rather complicated courses.

The terminal fibres mostly show little change in size, but slight change in size during their courses is not so rare. They end in sharp points in the greatest majority of cases but some fibres with small end knobs are also found. Though on rare occasions some fibres are found penetrating into the epithelium to pass over into intraepithelial fibres. Such intraepithelial fibres reach only the basal layer and never penetrate further into the middle or surface layer of the epithelium.

In Fig. 12 is shown a bifurcated sensory termination formed in one of the secondary papillae of a large pharyngeal papilla. The stem fibre, after losing its

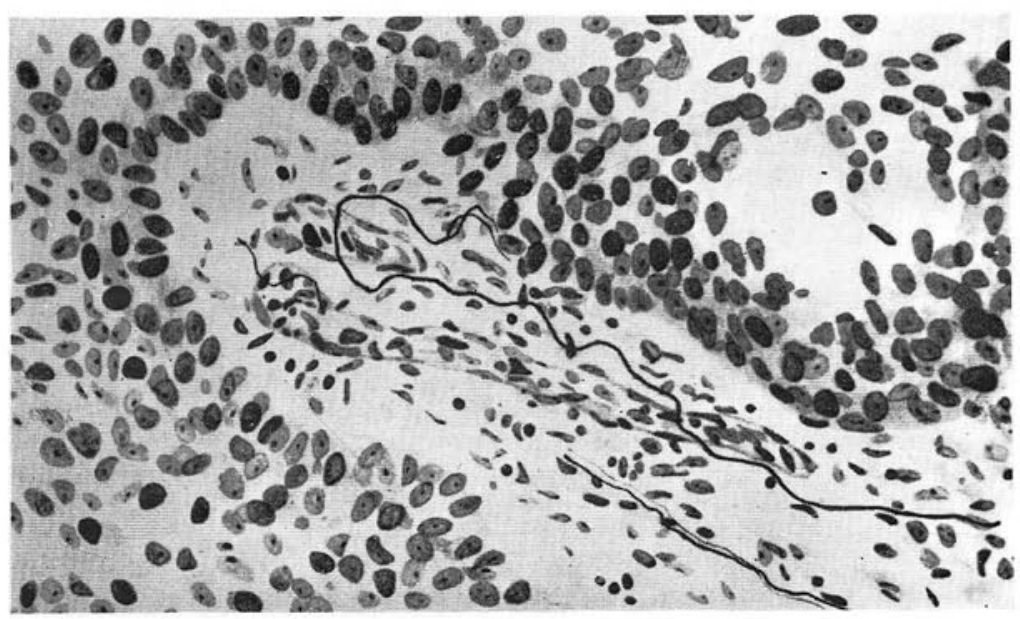

Fig. 12. A bifurcated sensory termination found in a secondary papilla of a large pharyngeal papilla of a snapping turtle. Details in the text. Same staining. $\times 320$.

myelin sheath, runs a gently undulating course showing little change in size, then describes a small loop before finally bifurcating into two short terminal fibres, which slowly taper off into sharp points just beneath he epithelium. Another bifurcated sensory termination, found subepithelially in a small pharyneal papilla, is shown in Fig. 13. The stem fibre, after losing the myelin, bifurcates into a thick fibre and a thin fibre, which both run straight toward the basis of the epithelium, and end close to it, the thick fibre in a sharp point and the other in a small endknob. In Fig. 14, we see an unbranched (u) and a branched (b) terminations both formed by stem fibres running rather straight courses and found in one of the secondary papillae of a pharyngeal papilla. In this papilla, we find also a powerful nerve plexus containing two ganglion cells.

In Fig. 15 is shown a branched termination of looped type of a considerably complex construction formed close to the epithelium of a large pharyngeal papilla. Its stem fibre (s) runs a perceptibly looped course, sending out $3-4$ fine terminal 


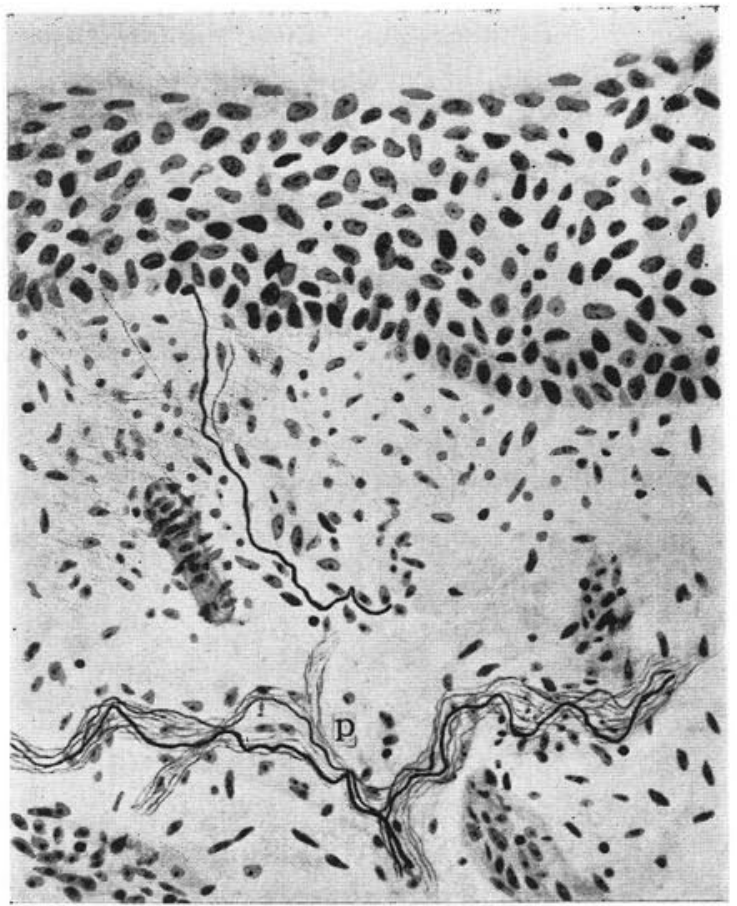

Fig. 13. A bifurcated sensory termination formed direct beneath the epithelium of a small pharyngeal papilla of a snapping turtle. One thick terminal fibre ends in a small end knob, while another fine one in a sharp point. $p$ intrapapillar plexus composed of many fine vegetative and some thick sensory fibres. Details in the text. Same staining. $\times 280$.

Fig. 14. An unbranched $(u)$ and a bifurcated $(b)$ sensory terminations formed subepithelially in a secondary papilla of a large pharyngeal papilla of a snapping turtle. $n$ intrapapillar plexus containing 2 small apolar ganglion cells. Same staining. $\times 400$.

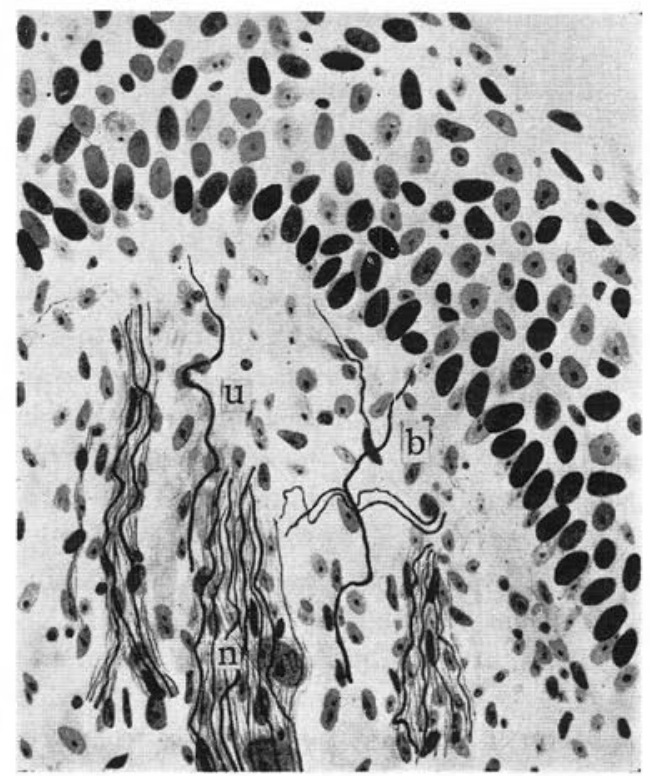




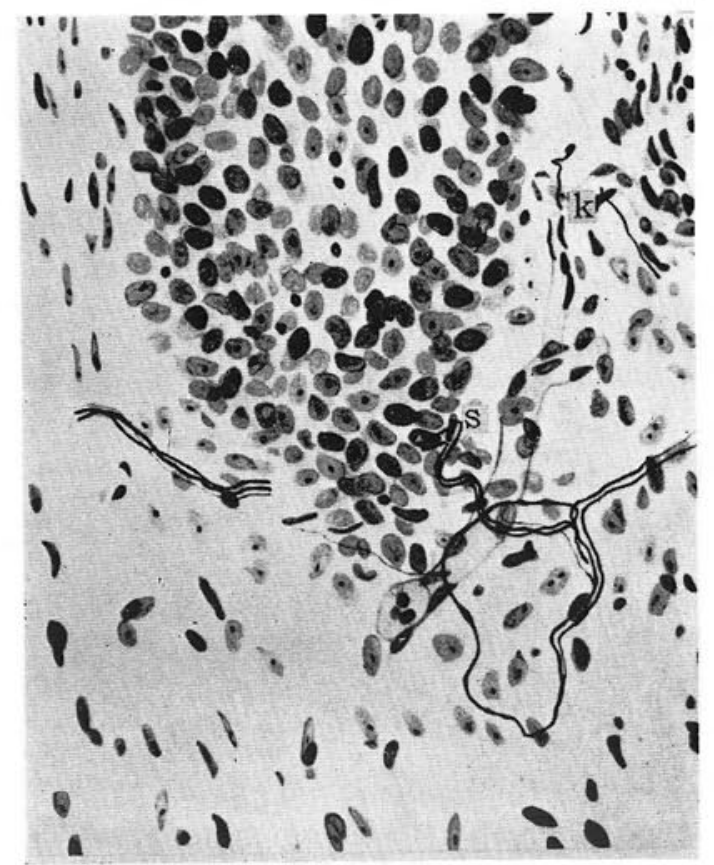

Fig. 15. A branched sensory termination of looping type formed subepithelially in a large pharyngeal papilla of a snapping turtle. $s$ stem fibre, $k$ an unbranched sensory terminal fibre ending in a small end knob. Details in the text. Same staining. $\times 320$.

fibres all ending sharply in the meantime. The stem fibre in the course forms 2 3 small varicose swellings. In the right upper part of the figure you may see an unbranched sensory termination with an end-knob formed close beneath the epithlium.

Fig. 16 shows an unbranched sensory termination originated in a thin stem fibre found along the epithelium of the basis of a pharyngeal papilla. This fibre runs into the basal layer of the epithelium before ending sharply therein. Besides, we see two very thick sensory fibres running between the pigmented connective tissue cells in this figure.

The nerves coming into the oesophagus of snapping turtle artle are probably derived from the vagal nerves and the cervical sympathetic trunk, as in man and other animals. These nerves, while repeatedly ramifying and anastomosing, run into the adventitia of the oesophagus where they form loose nerve plexus. In man and mammals, no ganglion cells have been found in the adventitia, but interestingly enough, small ganglia were sporadically found here in my turtle specimen (Fig. 17). I wish to call this plexus the "perioesophageal plexus."

The perioesophageal plexus sends nerve bundles of varying size further into the tunica muscularis, which, upon reaching the space between the outer and the inner muscle layes, pass over into the so-called AUESBACH's plexus (Figs. 8 and 18). Quite as in other animals rather large ganglia are found in this plexus. As 


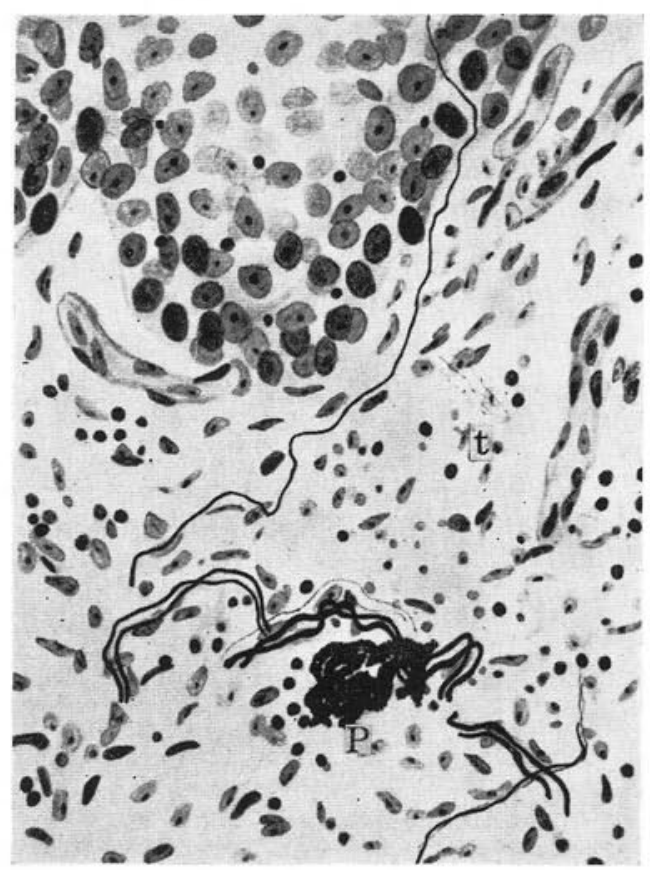

Fig. 16. An intraepithelial sensory fibre found in the basis of a pharyngeal papilla of a snapping turtle. $p$ pigment connective tissue cells. $t$ vegetative terminal reticulum. Details in the text. Same staining. $\times 400$.

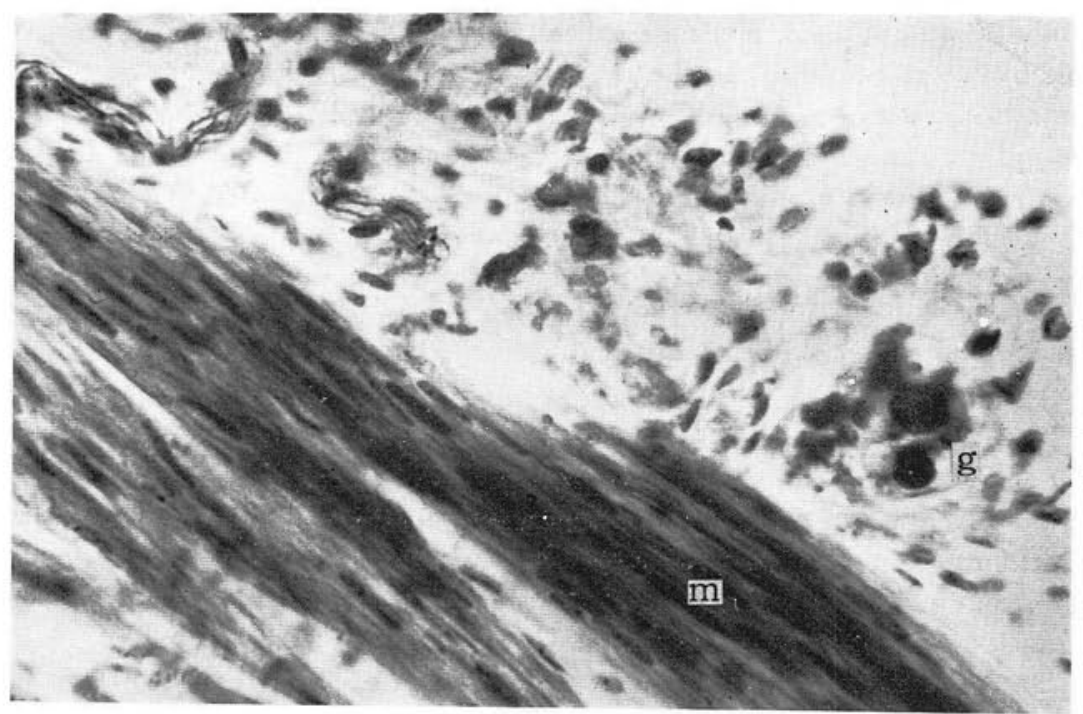

Fig. 17. Nerve bundles and a small ganglion containing 2 ganglion cells $(g)$ in the perioesophageal plexus of a snapping turtle. $m$ outer circular smooth muscle layer. Same staining. Photo $\times 400$. 


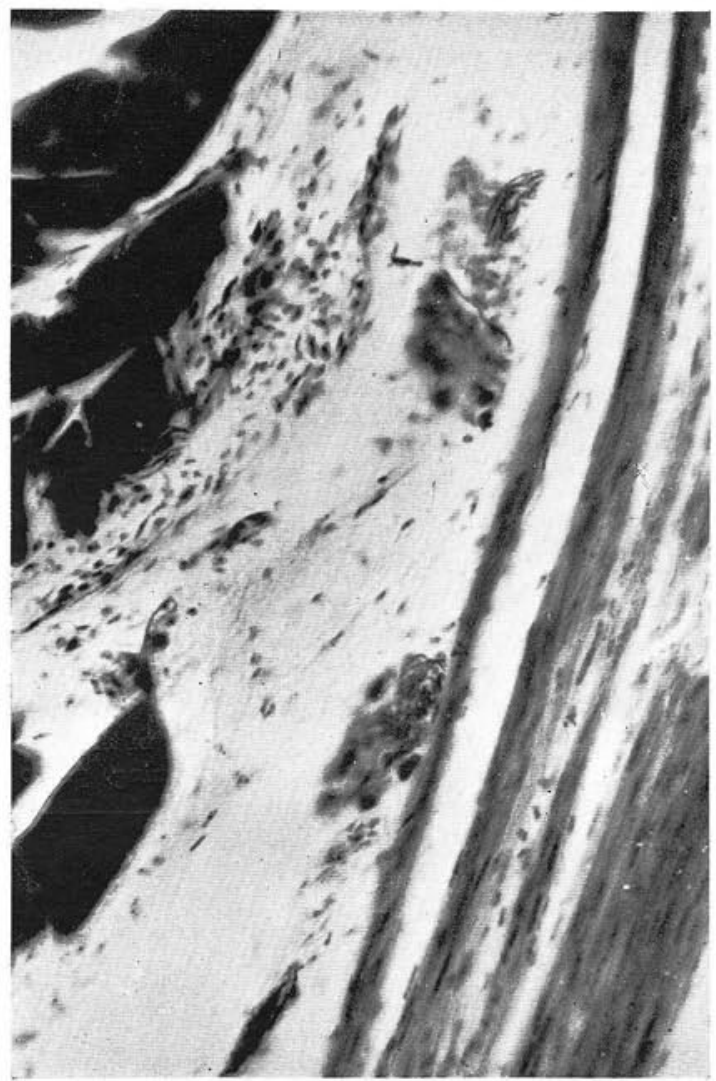

Fig. 18. Ganglia in the AUERBACH's plexus. High magnification of Fig. $8 \mathrm{~g}$. Photo $\times 200$.

stated above, the inner layer of longitudinal striated muscle fibres is absent in some parts of the oesophageal wall of this animal, in such parts, the AUERBACH's plexus is formed on the inner surface of the outer layer of the circular smooth muscle fibres, i. e., in the deep layer of the submucosa (Fig. 9), so as to merge with the plexus submucosus (MEISSNER). The MEISSNER's plexus is of course formed by the nerve bundles coming from the AUERBACH's plexus, as in other animals, but in the snapping turtle which has no lamina muscularis mucosae in its oesophagus, the plexus is more widely distributed, being found not only in the submucosa but also in the propria. The ganglion cells found in this plexus are much more numerous than in man and mammals - a very interesting finding. The comparatively larger ganglia are to be found in the deep layer of the submucosa, while the smaller ganglia with $2-3$ ganglion cells are found near its surface (Fig. 19). Besides, some solitary ganglion cells may be found here and there.

The ganglion cells found in the perioesophageal, the AUERBACH's and the MEISSNER's plexus (Fig. 20), as those in the pharyngeal mucous membrane, show weak multipolarity and clearly indicate their sympathetic nature. Many apolar 


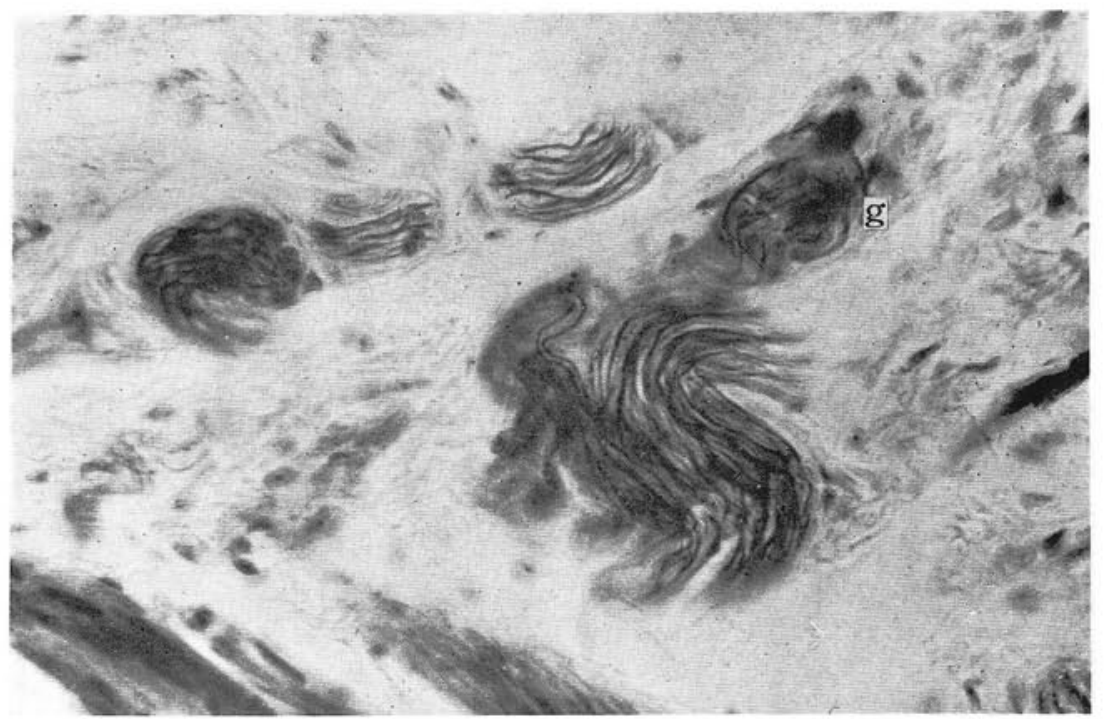

Fig. 19. A small ganglion $(g)$ containing $2-3$ ganglion cells in the MEISSNER's plexus in the oesophagus of a snapping turtle. Same staining. photo $\times 400$.

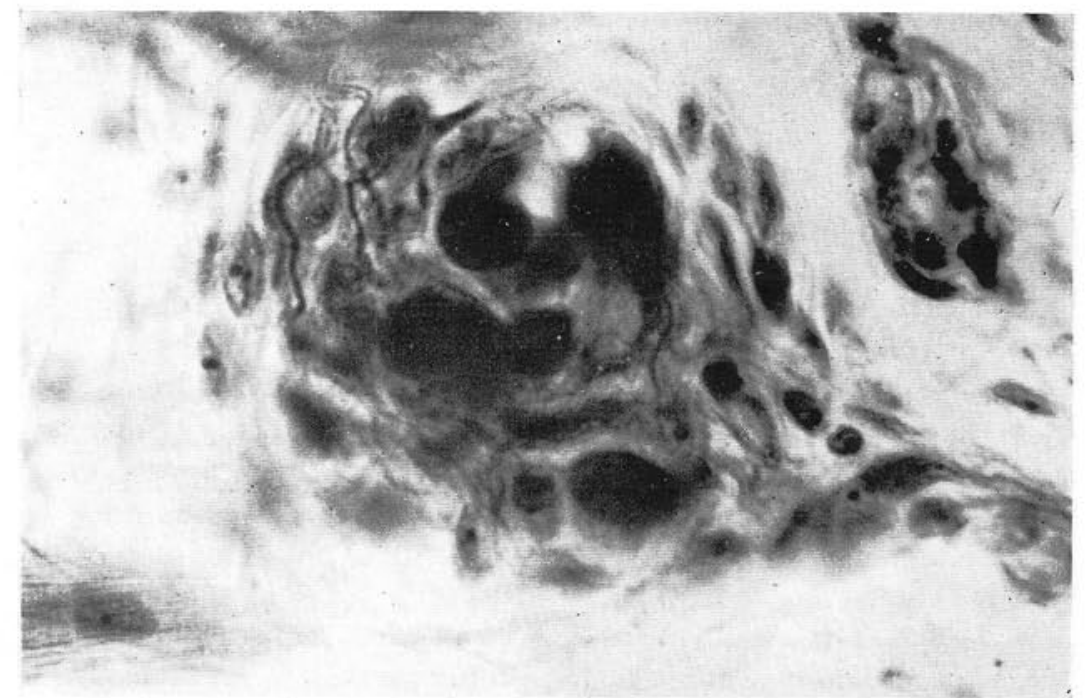

Fig. 20. Ganglion cells showing a weak multipolarity in a small ganglion in the AUERBACH's plexus in the oesophagus of a snapping turtle. Same staining. Photo $\times 800$.

ganglion cells are observed here too.

The nerve plexuses above found in the oesophagus of snapping turtle consist of fine nonmedullated vegetative fibres and thick medullated motor and sensory fibres. The vegetative fibres come into nervous anastomosis with those of the perivascular vegetative plexus and finally end in STÖHR's terminal reticula spread in various 
layers of the oesophageal wall.

Of the thick medullated fibres, the motor fibres end in motor end plates in the striated muscle layer, while the sensory fibres run out of the submucosa into the propria where they end most frequently beneath the epithelium. SADA has found a small number of simple corpuscular and multiform branched terminations in the tunica muscularis, in the ganglion of AUERBACH's and MEISSNER's plexus and in the propria, especially, subepithelially in the human oesophagus. In the oesophagus of snappgin turtle, there are indeed some sensory terminations formed by thick sensory fibres, but most of them are made of medium-sized medullated fibres, and their terminal modes are incomparatively more simple than those in the human oesophagus, only the simplest unbranched type and more rarely very simple branched type (chiefly bifurcated type) being represented, while no such corpuscular or complex branched terminations as found in the human oesophagus are ever found in that of snapping turtle. The terminal fibres usually end in sharp or blunt points and I could find here none ending in end-knobs or as intraepithelial fibres, unlike in the pharynx.

In Fig. 21 are shown unbranched terminations of $2-3$ sensory fibres, running

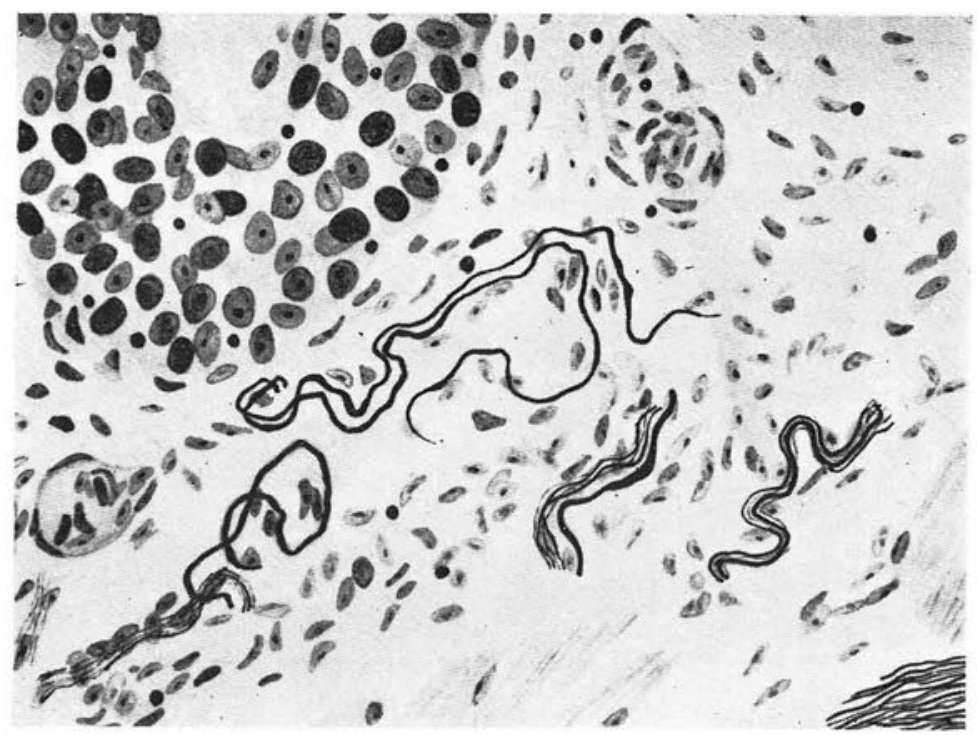

Fig. 21. Some unbranched sensory terminal fibres ending sharply found subepithelially in the oesophagus of a snapping turtle. Fine fibres are vegetative

fibres. Details in the text. Same staining. $\times 400$.

more or less looped courses and undergoing weak change in size. The unbranched termination of a rather thick fibre shown in Fig. 22 abruplty loses in size near the basis of the epithelium and ends there, without penetrating into the epithelium. Fig. 23 shows a bifurcated sensory termination formed in the oesophageal submucosa. Its terminal fibres run wavy courses while showing a little change in size and end somewhat bluntly. 


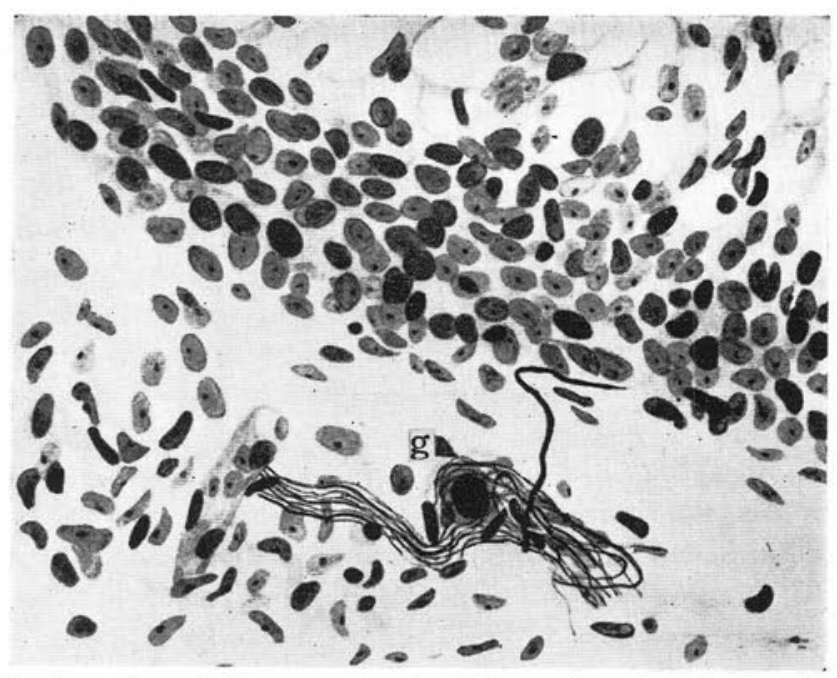

Fig. 22. An unbranched sensory terminal fibre ending sharply direct beneath the epithelium of the oesophagus of a snapping turtle. $g$ a ganglion cell in a small nerve bundle in propria. Details in the text. Same staining. $\times 400$.

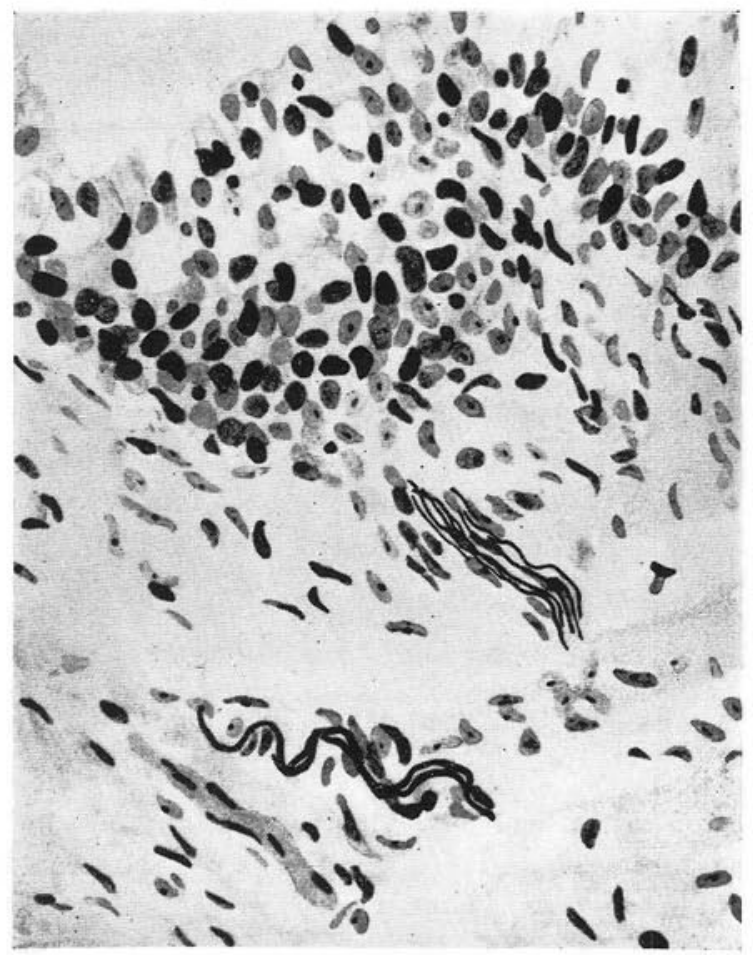

Fig. 23. A bifurcated sensory termination composed of thick terminal fibres ending sharply found in the submucosa of oesophagus of a snapping turtle. Details in the text. Same staining. $\times 400$. 
Thus, sensory terminations may be seen in formation in the mucous membrane of the oephagus of snapping turtle too, but these are much poorer than those in its pharynx in quantity as well as in terminal mode and are much worse developed than in the human oesophagus.

\section{Summary.}

It is of interest that, in the mucous membrane of the pharynx of Japanese snapping turtle, my so-called pharyngeal papillae resembling the lingual papillae may be found in quantity. The epithelium covering them is of an unhornified stratified flat type and the subepithelial connective tissue lacks mucuous glands. Longitudinal mucous folds are in formation in the oesophagus, covered by a stratified cylindrical epithelium and containing intraepithelial mucous glands. The lamina muscularis mucosae is absent; the tunica muscularis consists of an inner layer of longitudinal striated muscle fibres and an outer layer of circular smooth muscle fibres, but the former is formed only in the lateral sides of the oesophageal wail.

In the pharyngeal papillae, as in the lingual, well-developed nerve plexus composed of numerous sensory fibres and vegetative fibres is in formation. Small ganglia are found in this plexus as well as well as in the submucosal and the proprial plexus in the vicinity of the papillae. The ganglion cells in these ganglia are of sympathetic nature showing weak multipolarity but many of them are apparently apolar. The vegetative fibres end as always in STÖHR's terminal reticula in the pharyngeal mucous membrane of snapping turtle too.

No corpuscular or complex branched termination but only unbranched and simple branched terminations were found here. These are formed in the stocks of the pharyngeal papillae usuall beneath their epithelium, and originate mostly in medium-sized medullated fibres. Their terminal fibres run either nearly straight or looped courses and usually end sharply, but not rarely some end in small endknobs. Intraepithelial fibres are demonstrable in a very small number and are very poorly developed, penetrating only as far as into the basal layer of the epithelium before ending.

My so-called perioesophageal plexus formed in the adventia of the oesophagus, interestingly enough, contains small ganglia in some places. AUERBACH's plexus rich in ganglia is found between the outer and the inner muscle layers and MEISS. NER's plexus in the submucosa, and what is of highest interest is that ganglion cells are found in the MEISSNER's plexus here in a much larger quantity than in man and mammals.

It is needless to reiterate that the ganglion cells found in these plexuses are of sympathetic nature as those in the pharyngeal mucous membrane above and here too the fine vegetative fibres participating in the composition of these plexuses form STÖHR's terminal reticula as their terminations.

A rather large number of thick sensory fibres are found in the plexus of the oesophagus too. Most of these run from the submucosa into the propria and end there, mostly beneath the epithelium. Their terminations comprise no such corpu- 
scular or complex branched types as found in the human oesophagus, but only unbranched and simple branched (chiefly bifurcated) types, as in the pharynx, with terminal branches ending sharply or bluntly but never forming such end-knobs or intraepithelial fibres as found in the pharynx. Thus, the sensory fibres found in the oesophagus of snapping turtle are far poorer than the same in its pharynx, in quantity as well as in terminal mode.

\section{内容自 抄.}

スッポンの咽頭及び食道の組織像には哺乳動物の夫と可なり異なるるのが見ら れ. 彷ってその神経分布特飞知覚神経分布飞子特異所見の見られる事《興味深い。

先ず咽頭の粘膜には舌乳頭に類似の大小種々の咽頭乳頭の形成を見る，その上 皮は非角化性重層扁平上皮から成り，乳頭幹は多くの第 2 次乳頭を有す，尚拈粘 膜内《は粘液腺を欠く，食道飞は䋛走性粘膜策璧が見られ，上皮は重層円柱上皮， 中に上皮内粘液腺を含む，粘膜筋膜は欠損し，筋膜は内縦横敉筋層と外輪平滑筋 層と飞分れ，前者は背腹両側中央部には見られない。

咽頭乳頭内には舌乳頭飞於けると同様, 多数の知覚線維と植物線維とから成る 神経叢の形成を見る。そしてこの中にも乳頭外神経叢に於けると同様, 所ふに神 経細胞が証明される。この細胞は弱い多極性を示し，交感神経所属である，知営 線維の終末は小体様或は複雑性分岐終末で表わされる事はなく，非分岐性及び単 純性分岐怡終末から成り，咽頭乳頭内特飞上皮下に発見される。終末枝は或は直 走或は係䇛状走行を示し，その先端は専ら尖鋭状に終るが，又稀ならず終末球に 終る，との他上皮内僅か儿大って終る上皮内線維す極く少量に発見される．

食道では先ず外膜内に食道周囲神経叢の形成を見，この中にも所々飞小神経節 が見られる、両筋層間には神経節に富んだ Auerbach 神経譜を見，粘脱下膜内の Meissner 神経丵は人及び哺乳動物に於けるよりも遙かに多くの神経練胞を含む. 以上の神経細胞は何れも交感神経所属を示す，食道の神経叢飞る可なり多くの知 覚線維が含まれ，その多くは粘膜下膜から固有膜内淮み，上皮下に終る，その 終末は人に於けると異って複雑な終末様式を示すことなく，こっでも非分岐性及 び単純性分岐性，特に 2 叉状分岐終末で表わされるに過ぎず，而もその終末枝は 尖鋭状或山鈍状に終り，終末球に移行するものも上皮内線維となるものも証明さ れない，即ち食道では咽頭に於けるよりる知覚線維の分布は遥かて劣勢である。

\section{References.}

Abe, R. : Histology and innervation of the cloaca and the penis of snapping turtle. Arch. hist. jap. 10 (1956). - Harting, K. : Über die Beteiligung des N. vagus an der Bildung der intramuralen Nervengeflechte des Oesophagus. Z. mikr.-anat. Forsch. 35 (1934). --Loffredo-Ampaolo, C. : Studio istologico sulla fine innervazione sensitiva delle tuniche esofagee. Boll. Soc. ital. biol. sperimet. 27 (1951). - Monma, R.: On the histology and 
innervation of rectum and anus of snapping turtle. Arch. hist. jap. 14(1958). - Nakayama, T.: Histological studies on nerves in human tongue papillae, especially on sensory nerve endings. Tohoku Igaku Zassi. 33 (1943). - Ohy ama, T. : Histology and innervation of testicle, spermatic ducts, urinary bladder and urethra of snapping turtle. Arch. hist. jap. 14(1958). - Sada, T. : Microscopic studies on innervation of human oesophagus. Psyeh. et neur. jap. 46 (1942). - Sato, M. : Histological studies on innervation of pharynx in adult human. Tohoku Igaku Zassi. 46 (1952). - Innervation of pharynx in 10th month human embryo. Tohoku Igaku Zassi. 46 (1952). - Seto, H.: Studies on the sensory innervation (Sensibility of man). (Jap.) Tokyo and Osaka, Igaku Shoin, 1957. - Sugamata, G.: Innervation of inferior oesophagus and pars cardiaca ventriculi in dog. Arch. hist. jap. 7 (1955). 